are, as has been commonly assumed, isostructural. X-ray photographs of mesolite are very similar to those of natrolite, but show distinct differences. The space-group is $\mathrm{C}_{2}$.

Dr. A. E. Mourant: "The dehydration of thomsonite."

A study of the dehydration of thomsonite by the isobaric method. The results, obtained some years ago, are supplementary to those obtained by Hey by the isohydric method and differ from them in some respects. Dehydrated thomsonite does not absorb air. The lattice-shrinkage reaction has been further investigated.

Mr. F. J. Turner: "Note on the occurrence of piedmontite in quartz-muscovite-schist from the Shotover valley, Western Otago, New Zealand."

The description of piedmontite in schist occurring as boulders in the Shotover River. The mineral has not previously been recorded from New Zealand.

\title{
CORRESPONDENCE.
}

\section{THE BEACHES OF GOWER.}

Sir,-I should be obliged if I might reply to the criticisms of my paper on the ancient beaches of Gower (Proc. Geol. Assoc., xliii, 1932, 291) contained in Mr. Baden Powell's letter in the May number of the Geological Magazine (LXX, 1933, 239).

In the first place I would say that none of the beaches, other than the Patella Beach, which I described had previously been recorded. Of those which Mr. Baden Powell had reported to occur, I was unable to distinguish his fossiliferous 50 foot beach above his 25 foot beach ; and I found it impossible, for reasons given in my paper (p. 296) to separate his 25 foot beach from the equivalent of Mr. Wright's 10 foot pre-Glacial beach. I scarcely provide "confirmation" of Mr. Baden Powell's conclusions, therefore.

The remainder of his criticisms are adequately answered in the paper itself.

I specifically distinguished the Neritoides Beach from the Patella Beach on stratigraphical grounds: the minor differences between the faunas was a secondary aid in localities where the intervening terrestrial breccia is absent, but they are obviously not an absolute criterion and were not employed as such by me. The reasons for considering the conditions under which the Patella Beach was formed to have been cold, and those of the Neritoides Beach to have been warm, were not based on the evidence of the marine faunas found in the beaches, which is inadequate and equivocal, but on other grounds (see pp. 294-5, 300, 315, of my paper). Mr. Baden 
Powell's remark that the species listed in my paper as occurring in the Patella Beach constitute an almost, if not quite, impossible ecological assemblage, would suggest that he is under the impression that they lived where they are now found, which of course they did not : they occur as washed-up debris in a shore shingle, and precisely the same assemblage of dead shells may be found near high-water mark in many of the Gower bays at the present day.

I am in no confusion concerning the " 30 foot" beach of southern England, which was in 1927 and 1928 of Neolithic age, according to Mr. Baden Powell, but which is now probably Mousterian, according to the same authority. I was not concerned with that beach, I did not discuss it in my paper, and I have not attempted to affirm or deny its contemporaneity with any of the Gower beaches. Its correlation with the " 30 foot" beach of Gower (the Patella Beach) is Mr. Baden Powell's, not mine. On the other hand, Mr. Baden Powell reached the conclusion in 1927 (Geol. MAG., LXIV, 436), reiterated in 1928 (ibid.,LXV, 48), that the " 30 foot " beach in Gower (correlated with the beach at the same height in Scotland and the south of England) is of post-Glacial age. The remarks in my paper were supplementary to those of Tiddeman, Wright, and Charlesworth in attempting to show that it is nothing of the kind. For the stratigraphical evidence in Gower is abundant and overwhelming that the " 30 foot" beach (the Patella Beach) of that district is older than the oldest neighbouring Glacial drift, which is the Older Drift of South Wales ; it is therefore pre-Glacial so far as concerns the local application of that term. This was all I wished to assert, and I did not also desire to imply that it is necessarily pre-Pleistocene. It is, however, at least older than the Neritoides Beach and the Rhinoceros hemitoechus fauna associated therewith, which are of Late Acheulean or Early Mousterian age.

Geological Survey Office,

28 Jermyn Street, LoNDON, S.W. 1.

5th May, 1933.

T. Neville George.

\section{THE ICE AGE AND EARLY MAN IN YORKSHIRE AND NORTH LINCOLNSHIRE.}

Sir,-I have read with the greatest pleasure Professor P. G. H. Boswell's masterly Presidential Address delivered to Section $\mathrm{C}$ of the British Association at York this autumn. To the archaeologist it is an epoch-making paper, and perhaps it will not be amiss for me to animadvert upon his references therein to my work conducted in Yorkshire and in north Lincolnshire. Dealing with north Lincolnshire, Professor Boswell states (page 75) : "The correlation of the 